\title{
Exploring Language Learning Strategies of Activist English Students Department with High GPA
}

\author{
Siti Lailiyah \\ English Language Education Department, \\ UIN Sunan Ampel Surabaya \\ Chalifia Rafidah \\ English Language Education Department, \\ UIN Sunan Ampel Surabaya
}

\begin{abstract}
In education there is an major goal of going to any person to follow an education. The big goal was a result of education that can be short to measure a person to determine the future as what we know a knowledge that of the level of education in Indonesia is highly variation of this time, one is a student at the university. As for one outside factor that might affect the results of students' studies, they are actively engaged in some activity outside the campus and within the campus. The activities can help students to improve their skills in various ways. Students who participate in activities may be called active students. The benefits of many of the activities of one student can improve their social character toward others. As sasongko (2006) says is a student who is active in the organization, naturally having adequate social skills and values. As for the result of this proposal is about the use of different learning strategies does not affect their GPA highs whether they are outdoors or on campus. For the kind of method used is qualitative method and for the data collection using a Questionnaire and interviews. Data collection through to determine the experiences of participants in several organizations or activities, while using interviews is in order to communicate directly with participants. The finding from this research differences in the application of learning strategies that some people do have specific differences, but they do not affect the level of GPA they have when they are fully outdoors or on campus.
\end{abstract}

Keywords: active students, high GPA, student's strategies

\section{INTRODUCTION}

The learners have to be aware of what kind of learning strategies that are appropriate to use in order to get good competency and successful in learning. Succesful learners are laerners who spend a lot of time to do following things, one of them is using many different learning strategies (Brown,

\author{
Nur Afifatul Khoiriyah \\ English Language Education Department, \\ UIN Sunan Ampel Surabaya \\ Shovie Islachia Chorida \\ English Language Education Department, \\ UIN Sunan Ampel Surabaya
}

2002). Learning strategies are intentionally used and consciously controlled by the learners (Pressley with McCormick, 1995). When the learners choose strategies that are appropriate with their learning style, these strategies become a useful tool for active, conscious, and purposeful selfregulation of learning.

There are some aspects in learning strategies that should be known such as specific actions, behaviors, steps, or techniques like seeking out conversation partners, or giving oneself encouragement (Scarcella \& Oxford, 1992). Learning strategies are specific actions taken by a learner to make learning easier, faster, more enjoyable, more self-directed, more effective, and more transferable to new situation (Oxford, 1990). They include strategies for identifying the material that needs to be learned; distinguishing from other material if needed, grouping it for easier learning, and formally committing to memory when it does not seem to be acquired naturally.

Language learning strategies are categorized into direct strategies and indirect strategies (Oxford, 1990). Direct strategies are divided into memory strategies which is focus on remembering information, cognitive strategies which is spesific in uderstanding and producing language, and compensation strategies enable learner in using the language despite knowledge gaps (Zare, 2012). Then, indirect strategies do not directly involved using the language, but they support language learning (Zee, 2010). Indirect strategies also divided in three categories, those are metacognitive strategies which is focused on students' learning process, affective strategies assist students in monitoring emotional temperature, and social strategies focused on learning with others. Therefore, those learning strategies can be used by students help them in achieving their learning goal and getting a good academic performance, eventhough they have so many activities in outside. This thing seems to be very interesting topic to be investigated.

Considering the interest of this topic, there are some studies also studied in the similar topic. 
Zimmerman (2010) who studied about selfregulated learning strategies to achieve particular academic achievement has found in his study that all of the learner has intrinsic motivation and personal responsibility to achieve particular academic success. Those self-regulated students used a systematic of metacognitive, motivational, and behavioral strategies. Khandari (2015) studied about identifying learning strategies between successful learners and unsuccessful learners. Students are considered as successful or unsuccessful learner based on thir score from test. This study found that those kind of students applied some strategies, but the differences between them is the implication of the learning strategies with their ownself that make them to be succes or not in learning. Moreover, Rustam also studied a similar case in 2012. He found that successful learner mostly used metacognitive strategies and unsuccessful learner dominant in usingsocialstrategies.

Those previous studies mostly show that each learner has their own learning strategy. Almost of students were used metacognitive, cognitive, and social strategies, but not all students who applied same strategies will get same predicate as a successful learner. So, the successful of learning is definitely depend on the students itself, the way they optimize the use of the strategies in learning process. However, those particular studies have a similar discussion with this study, but there were also significant differences especially the subject of the study and the scope of the study. It also has quite different aim with this study. So, that's why this study is important to be conducted.

This study will concern to the students who have high GPA and have many activities inside and outside the college. The aim of this study is to investigate the learning strategies that used by particular students who got high GPA in academic and have many activities. Questionaire and some interviews will be conducted to get a valid data to answer the research question. So, hopefully this study will help other students who can also apply the strategies for themselves. This study also might be useful for the other researcher and educator who want to study about similar issue.

\section{METHOD}

In this study, the researcher use qualitative approach as a research design. Some interviews will be conducted to get a valid data to answer the research question. This research is called qualitative research because it will use interviews to get the data collected.In this research the way the researcher collects data is using questionaire and some interview that will be done to the students of English Education Department of UIN Sunan Ampel Surabaya as a population area which the researcher is trying to get information from. According to Burns (1990:62) "Population is an entire group of people or objects or events which all have at least one characteristics one common, and must be defined specially and unambiguously". Then, The researcher conducts the interview three students of English Education Department of UIN Sunan Ampel Surabaya who got high GPA in academic and have many activities.

Interview is activity that involves interviewer will gives some questions to be answered by interview. Thus, in this case, the interviewer has to conduct collecting data with doing interaction or communication directly. But, it can be conducted face to face or through via electronic.Then, the data collection will be analyzed by controlling, organizing, grouping, giving the code and categorizing. Those data will be gathered and classified then will be analyzed by qualitative descriptive approach and finally find the conclusion as in the end of research process.

\section{FINDINGS AND DISCUSSION}

\section{Findings}

Based on the data from some participants that already analyzed by the researchers, the researcher got the research finding. There are some similars and differents point of vies from them. The first participant, He had sixth semester of English Education Department. At the time, he had score of GPA more than 3 points. Another side, He got anapportunityto study abroad as a students exchange in Polandand and got appreciation from the faculty as $\mathrm{s}$ students that has the higher GPA at fourth semester. He was not only as a students that focused to get the good achievement in academic and non academic, but he also had join in some organizations including in Students Association of English Education in the College (HIMAPRODI PBI) and in outside the college such us IALF Surabaya. He participate in his organization as a coordinator of language development in himaprodi and as a coordinator of public relation in IALF and as a mentor for Basic Program Course in IALF. He did a lot of contribution in there because he spent so many time to do his responsibilties in exploring the job coordinations of the organizations. Moreover, beside he was busy in his activities in outside the home, he also had responsibilities in his natural life such as controling menegement time. In everyday, he wake up at 5 o'clock every day, but he sleptagain until 7 o'clock except on Saturday and Sunday I have another activity. Then, he studied part time in the campus and next part time he always spent it in IALF or just played an online game. In the noon, $\mathrm{He}$ slept earlier at 9 or 10 o'clock, and I did some assignments or duties during one into two hours in the midnight, this is my favorite time that I get my full concentration and inspiration. So that, actually he just spent no much time to studies in everyday. 
The second and third participant have some similarities with the first participant who got more than 3.5 for their GPA, especially close to 3.7. Moreover, both second and third participant won similar competitions outside the campus, those are speech contest and debate. They are as the first and third winner from those similar competitions. They also joined same organizations that is HIMAPRODI PBI. The second participant is as a steering committee in Language division and the third participant is as a secretary of HIMAPRODI PBI. Looking at their position in the organization, it showed that they have a lot of contributions for that organization. In addition, based on what have they explained about their daily activity in a day and weekly, almost of both second and third participant are a teacher from some courses and school every day. There are no days without teaching. While they didn't have any schedule in campus, they have schedule in teaching from 7 a.m until 5 p.m in a school, but if they have a schedule in campus, they still teaching but suit both schedule in campus and teaching. However, those two participants told that they still have time to have fun and hang out with their friend in the evening. Considering from those a lot of activities and achievement that they got, certainly that they have strategies in learning process.

Related with the strategies from all of those participants, the result of the questionnaire will show the strategies that they use start from strategies in speaking skill, listening skill, reading skill, and writing skill.

1. In Speaking skill

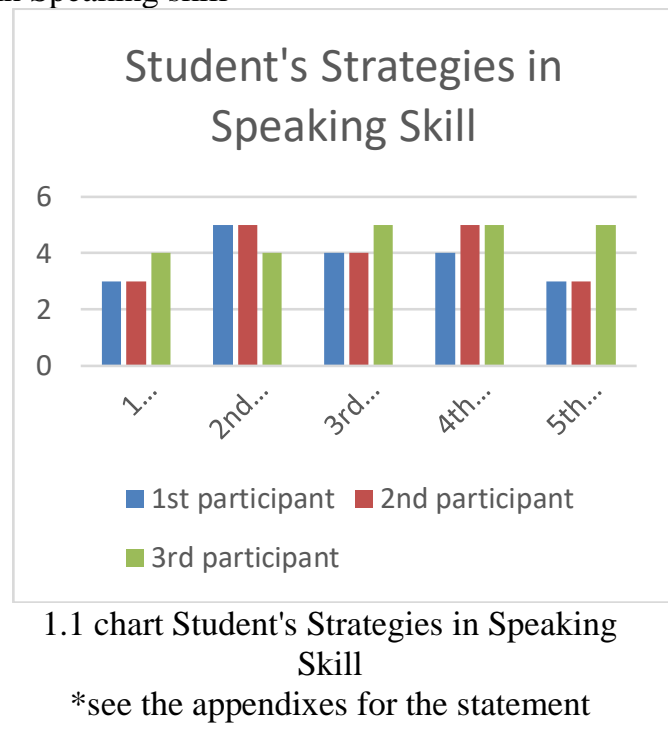

Based on the chart above, it shows that there are bit similarities in the strategies that used by all participants. There are two strategies that mostly used even it by $1^{\text {st }}, 2^{\text {nd }}$, or $3^{\text {rd }}$ students, they are $2^{\text {nd }}$ and $4^{\text {th }}$ statement.
2. In Listening skill

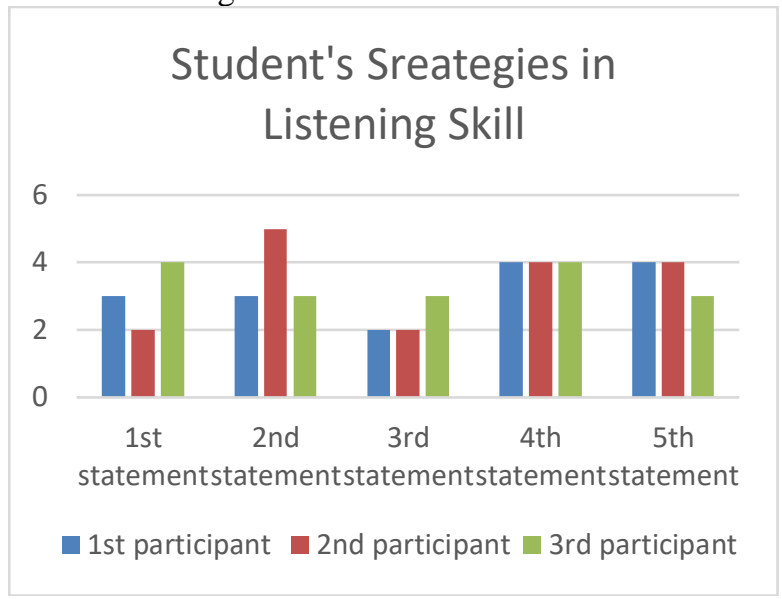

\section{1 chart Student's Strategies in Speaking Skill \\ *see the appendixes for the statement}

Based on the chart above, it shows that there are many differences in the student's strategies, but the chart also shows that the $4^{\text {th }}$ statement is mostly used by all of the participant.

3. In Reading skill

\section{Student's Strategies in Reading Skill}

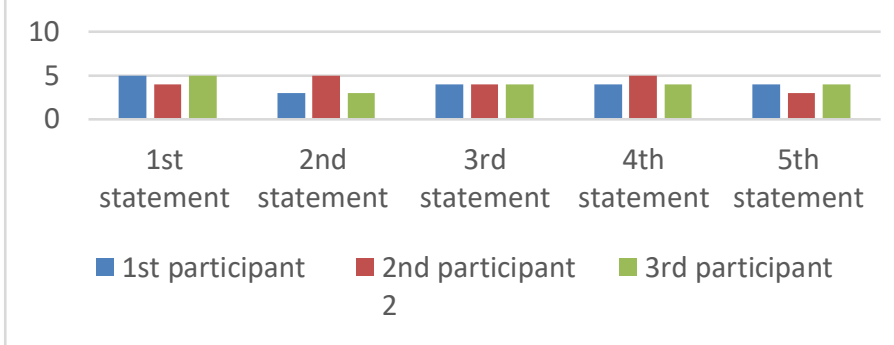

\section{1 chart Student's Strategies in Speaking Skill \\ *see the appendixes for the statement}

Based on the chart above shows that some students have similar strategies. They are the first and the third participant who have similar frequency in using same strategies. 


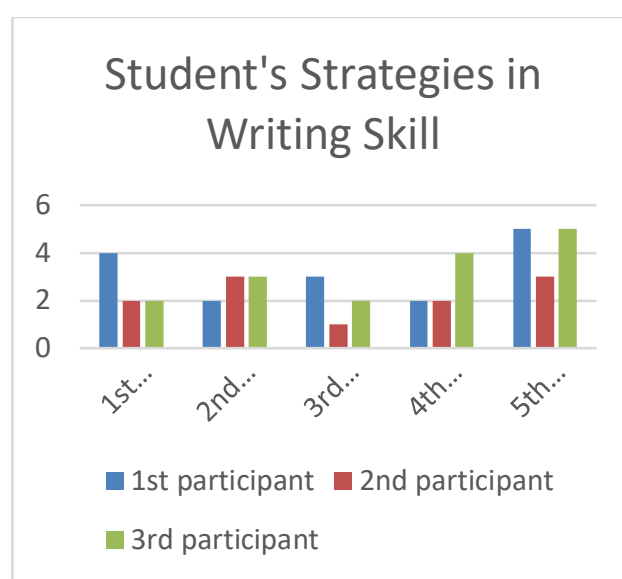

4.1 chart Student's Strategies in Speaking Skill

*see the appendixes for the statement

Based on the chart above, it shows that almost students have dissimilar strategies, the most frequent strategies is the $5^{\text {th }}$ strategies that used by first and third participant.

\section{Discussion}

Based on research finding in above, the researchers got some informations that would be related with some theories that used by this study as a theoritical framework. Therefore, This study has proposed a classifi cation of language learning strategies consisting of three subcategories: metacognitive, deep level cognitive and surface level cognitive strategies. This classifi cation is not final; further studies need to be done to replicate the fi ndings related to strategies so that more consistent findings become available within and across populations. Particularly important is more information on how students from different age levels and different educational settings use language learning strategies in EFL settings. The implications suggested in this study that English teachers should encourage their students to use metacognitive strategies and that they still need to teach grammar, may be applicable to a context that has similar conditions with those of the participants in this study. Language learning strategies also need to be included in teacher training curriculum and staff development program so that English teachers will be familiar with effective learning strategies for their students. Further studies need to be done to replicate the fi ndings of this study by assessing the use of learning strategies with different measurementmodes so that more consistent findings becomes available within and across populations. Thus, In this study, the researcher found that there are differences learning strategy that used by students activist eventhough they got the good the high GPA in the college, it means that there is no spesific learning strategy that help or influence in getting the high GPA and become succesfull student or not.

\section{CONCLUSION}

Related with the result and the discussion above, the result of interview showed that all of those participants got a high GPA and achieved some nonacademic achievement, moreover they also have many activities inside and outside campus such as joining and participating in their organizations, teaching some courses and schools, learning in campus, doing their homework. In addition, the result of questionnaire related with the strategies that they used in learning shows that each student has variant preference of strategies. So, they have different preference in using learning strategies, whether strategies in speaking skill, listening skill, reading skill and writing skills.

\section{REFERENCES}

[1] Apple1, Daniel and Duncan, Wendy, et.al; September 2016, Volume 8 Issue 2; Key Learner Characteristics for Academic Success; International Journal of Process Education

[2] Hismanoglu, Murat. 2000. Language Learning Strategies in Foreign Language Learning and Teaching. TESL Journal, Vol. VI, No. 8

[3] Khandari, Anggreini, Ag. Bambang Setiyadi, Ari Nurweni; 2014; Identifying Learning Strategies Between Successful And Unsuccessful Learners In Reading Comprehension.

[4] Nonis, Sarath A., and Hudson, Gail I.; January 2006; Academic Performance of College Students: Influence of Time Spent Studying and Working; Arkansas State University

[5] Oxford, Rebecca; January 2001; Language learning styles and strategies: An overview; University of Alabama at Birmingham

[6] Setiyadi, Bambang. 2016. Language Learning Strategy Questionnaire (LLSQ): A Measurement to Identify Students' Learning Strategies and Prepare the Success of Learning English in the Indonesian Context (Empirical Evidence). Yogyakarta: GrahaIlmu

[7] Suran, Rose Dayang Anak, and Yunus, Melor Md.;2010; A Survey on Students' Learning Styles and Strategies in a Rural Secondary School in Meradong District; Universiti Kebangsaan Malaysia, Malaysia 